(C) 2014

Лук'янова Г. О., доктор ветеринарних наук

ПФ НУБіП України «Кримський агротехнологічний університет»

\title{
ОСОБЛИВОСТІ ЕПІЗООТОЛОГІЇ АНОПЛОЦЕФАЛІДОЗІВ КОНЕЙ В УМОВАХ АР КРИМ
}

\section{Рецензент - доктор ветеринарних наук В. О. Свстаф'єва}

Вивчено сезонно-вікову інвазованість коней аноплочефалятами в різних клімато-ландшафтних зонах АР Крим. Максимальна аноплочефальозна інвазія у коней реєструється в передгірній $і$ гірській зонах. У степовій зоні даний гельмінтоз взагалі не спостерігали. Частіше виявляли збудників виду Anoplocephala perfoliata (y 63 коней із 71 уражених аноплоиефалами -87,3\%). Найбільшу інвазованість спостерігали в осінній період. Молоді тварини 1-3-річного віку мали найвищі показники ураженості цестодами травного каналу $(E-26,3 \%)$. Дорослі коні були інвазовані лиме на 5,7\%.

Ключові слова: коні, аноплочефалята, епізоотологія, екстенсивність інвазії.

Постановка проблеми. Серед заходів, що сприяють зростанню поголів'я коней, важливе значення має попередження та ліквідація гельмінтозних захворювань, одними 3 яких $є$ аноплоцефалятози. Аноплоцефалятози травного каналу завдають неабиякої економічної шкоди конярству. Дослідження показали, що 3 даними гельмінтами пов'язані деякі види кольок у коней $[1,8]$. У ослаблених тварин паразити споживають значну кількість поживних речовин і вітамінів, викликаючи стан стресу і подальше ослаблення, що ускладнює перебіг захворювання [5].

Аналіз основних досліджень і публікацій, у яких започатковано розв'язання проблеми. Вивченню епізоотології цестодозних хвороб коней присвячена значна кількість робіт вітчизняних і зарубіжних вчених $[3,4,7]$. Однак особливості аноплоцефалятозної інвазії коней у Криму майже не вивчалися.

Відомо, що перебіг епізоотичного процесу за паразитарних захворювань визначають поряд 3 іншими факторами клімато-географічні умови. На інвазованість тварин паразитами, в тому числі й аноплоцефалами, істотно впливають кліматичні умови території [6].

У Криму питання особливостей екології паразитів травного каналу коней залишаються недостатньо вивченими і спираються на роботи вчених проведені на території україни [2]. У зв'язку 3 цим потребують вивчення питання зональних особливостей епізоотології аноплоцефалятозів та розробки ефективної комплексної системи захисту коней від цестодозних інвазій.

Мета і завдання досліджень. Метою роботи було вивчення сезонно-вікової інвазованості коней збудниками аноплоцефалятозів у різних клімато-ландшафтних зонах АР Крим.

Для цього вирішували наступні завдання: дослідити зараженість коней цестодами в різних клімато-ландшафтних зонах АР Крим; визначити сезонне ураження коней аноплоцефалятами; встановити вікову інвазованість коней цестодами травного каналу.

Матеріали і методи досліджень. 3 метою вивчення інвазованості коней аноплоцефалятами в господарствах різних клімато-ландшафтних зон АР Крим були проведені клінічні, копроовоскопічні й патолого-анатомічні дослідження. Гельмінтокопроскопічні дослідження проводили згідно зі стандартизованими методами Г. А. Котельникова і В. М. Хрєнова. Інтенсивність інвазії визначали підрахунком кількості яєць гельмінтів у трьох грамах фекалій і шляхом підрахунку гельмінтів під час неповного гельмінтологічного розтину вимушено забитих тварин. Визначали сезонні та вікові особливості інвазування коней цестодами за даними щомісячних досліджень.

Результати досліджень. У Криму виділяють п'ять основних агрокліматичних районів: 1 південнобережний, 2 - степовий, 3 - нижній передгірний, 4 - верхній передгірний, 5 - гірський райони. Найбільша чисельність коней зосереджена в степовому, нижньому і верхньому (північному) передгірному районах.

Волога передгірна й гірська зони займають близько $30 \%$ території АР Крим і є найбільш сприятливими для тваринництва. Тут поголів'я коней коливається в межах 1,5-2 тисяч голів.

У процесі обстеження коней різних господарств Криму тільки в одному 3 них (ПСП а/ $\phi$ «Зеленогорск» Білогірського району) виявлені тварини, уражені цестодами 3 підряду Anoplocephalata. Вони були віднесені до видів Anoplocephala perfoliata i Paranoplocephala mamillana. Інвазованість коней (71 тварина) даними цестодами від загального числа обстеже- 


\section{ВЕТЕРИНАРНА МЕДИЦИНА}

них у республіці (636 голів) склала лише 11,2 \%. На території неблагополучного господарства аноплоцефалами була уражена 71 тварина, що становило 36,2\%. Частіше виявляли збудників виду Anoplocephala perfoliata (у 63 коней iз 71 уражених аноплоцефалами $-87,3 \%$ ).

Найбільш інтенсивно інвазованим аноплоцефалятами виявився молодняк у віці до 1-3-х років (EI - 26,3\%). Серед лошат до одного року екстенсивність цестодозної інвазії становила 9,6 \%. Дорослі коні були інвазовані лише на 5,7 \%.

Аналізуючи результати щомісячних розтинів коней (34 тварини) у різні періоди року відмічали, що найбільше аноплоцефалят у кишках спостерігається восени (32-38 паразитів).

Взимку й навесні кількість гельмінтів у кишках була дещо нижчою (25-29 і 10-14 відповідно). Влітку знову відбувалося зростання чисельності паразитів в організмі тварин (1822 цестоди).

Співставляючи дані сезонної динаміки аноплоцефалятозів у зональному аспекті, слід відмітити закономірність більш інтенсивного ураження цестодами коней усіх вікових груп верхньої передгірної й гірської зон республіки. В умовах цих зон регіону інтенсивне ураження тонких кишок усіх груп коней паразитами спостерігали в осінній період. Це, на нашу думку,

\section{БІБЛІОГРАФІЯ}

1. Андреева М. В. Патогенная роль цестод лошадей и биология развития цистицеркоидов аноплоцефалид в орибатидных клещах / М. В. Андреева // Перспективы направления интегрирования экологических, эпидемиологических и эпизоотологических проблем в республике для совершенствования ветеринарного обслуживания. - Якутск, 1994. - С. 63-64.

2. Галат М. В. Змішані інвазії коней (поширення, діагностика, лікування): автореф. дис. на здобуття наук. ступеня канд. вет. наук: спец. 16.00.11 «Паразитологія»/ М. В. Галат. - Київ, 2010. - 17 c.

3. Латко М. Д. Испытание лечебной эффективности препаратов фенасал и агроник при цестодозах молодняка лошадей / М. Д. Латко // Материалы докладов научной конференции «Теория и практика борьбы с паразитарными болезнями». - М., 2005. - Вып. 6. - С. 210-211. обумовлено сильною контамінацією випасів зараженими цистицеркоїдами гельмінтів орибатидних кліщів в осінній період. Висока щільність проміжних хазяїв гельмінтів (6-8 тис. екз. на 1 м $^{2}$ високогірних випасів) забезпечувала постійне та інтенсивне зараження тварин цієї зони. У нижній передгірній зоні інтенсивність інвазування коней була меншою.

У степовій зоні даний гельмінтоз взагалі не реєстрували. Відсутність аноплоцефалят серед поголів'я коней степової зони можна пояснити несприятливими умовами для орибатидних кліщів, чисельність яких на даних територіях дуже низька. Крім того, коні даної зони випасаються рідко і на обмеженій території, що пов'язано 3 технологією їх утримання.

У даному випадку перезараження може відбуватися лише кишковими гельмінтами в разі потрапляння збудників інвазії з кормами й водою. Це зменшує ризик зараження, особливо за умови, коли тварин утримують і годують індивідуально, не контамінованими кормами, крім того відсутній контакт між особинами.

Висновок. Максимальна аноплоцефальозна інвазія у коней в АР Крим реєструється в осінній період у молодих тварин 1-3-річного віку в передгірній і гірській зонах.

4. Латко М. Д. Распространение основных гельминтозов лошадей в разных климатических зонах / М. Д. Латко // Материалы докладов научной конференции «Теория и практика борьбы с паразитарными болезнями». - М., 2006. Вып. 7. - С. 211-214.

5. Опыт борьбы с паразитозами лошадей / Кадыров Н. Т., Аубакиров С. А., Ибраев Б. К. [и др.] // Ветеринария. - 1991. - № 7. - С. 32-34.

6. Сохроков 3. A. Сезонная динамика аноплоцефалятозов жеребят в КБР / 3. А. Сохроков // Вестник ветеринарии. - Ставрополь, 2000. № 7. - C. 68-71.

7. Anoplocephala perfoliata in horses in Sweden: prevalence, infection levels and intestinal lesions / A. Nilsson, B. L. Ljungstrom, J. Hoglund [et al.] // Acta Vet. Scand. - 1995. - Vol. 36. - P. 319-328.

8. Proudman C.J. The equine tapeworm / Proudman C. J. // Equine veter. Educat, 1994. Vol. 6, № 1. - P. 9-12. 